\section{Solar America City - San Diego, California}

San Diego is a "hotbed" of solar activity! In June 2007, San Diego was selected as a Solar City by the U.S. Department of Energy because of its commitment to adopting solar technology at the local level. Municipal government, businesses, and nonprofit organizations are working together to meet the goal of 50 megawatts (MW) of solar installed by 2010 .

\section{Solar Panels Save Taxpayer Dollars}

Environmentally friendly, the City's PV (photovoltaics) systems save almost $\$ 170,000$ annually in energy costs.

The U.S. Environmental Protection Agency ranks the City of San Diego as fourth in the nation for producing and using environmentally preferable green energy. Using renewable energy reduces carbon dioxide emissions equivalent to planting 40,187 acres of trees.

In the San Diego region, the MW installed has increased by more than 35\% during the past 5 years, and the number of PV systems that have helped offset the utility grid has topped more than 33 MW. The City of San Diego alone has contributed more than one third of the region's installed MW.

\section{Future PV Installation Sites}

- New Main Library

- Municipal Gymnasium

- Palisades Building

- Mission Valley Library

- Casa del Prado

\section{Regional Partners}

City of San Diego - Environmental Services Department www.sandiego.gov/environmental-services/index.shtml

\section{California Center for Sustainable Energy}

www.energycenter.org

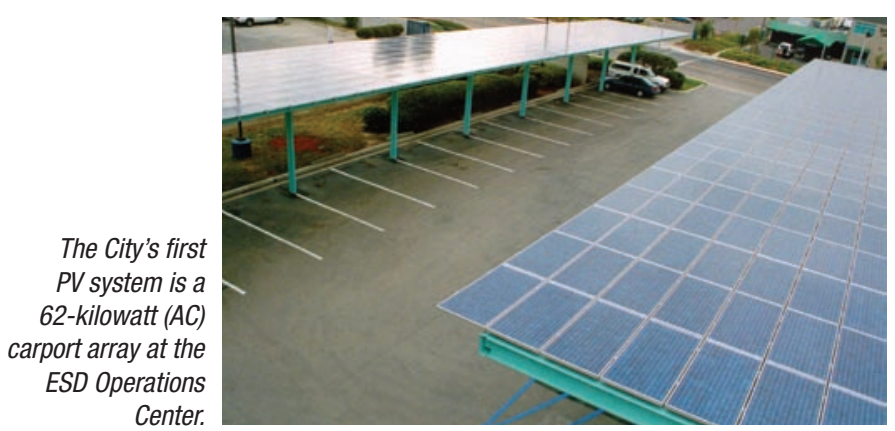

\section{San Diego PV Installations}

1. Nobel Athletic Park and Recreation Center, 8810 Judicial Drive

- 20-kilowatt (AC) system

- completed April 2007

2. Police Northwestern Division Substation, 12592 El Camino Real, Carmel Valley

- 20-kilowatt (AC) rooftop system

- completed March 2007

3. Alvarado Water Treatment Plant, 5530 Kiowa Drive, La Mesa

- 945-kilowatt (AC) system atop three water reservoirs

- completed February, 2007

4. North Clairemont Branch Library, 4616 Clairemont Drive

- 16-kilowatt (AC) rooftop system

- completed May 2006

5. Oak Park Branch Library, 2802 54th Street

- 20-kilowatt (AC) rooftop system

- completed May 2006

6. Canyonside Recreation Center, 12330 Black Mountain Road

- 29-kilowatt (AC) rooftop system

- completed May 2006

7. George L. Stevens Senior Center, 570 S. 65th Street

- 7-kilowatt (AC) rooftop array

- completed March 2006

8. San Ysidro Fire Station 29, 179 W. San Ysidro Boulevard

- 7-kilowatt (AC) rooftop system

- completed July 2005

9. Police Headquarters, 1401 Broadway

- 30-kilowatts (AC) rooftop system

- completed June 2004

10. Metropolitan Wastewater Department's Operation Complex (MOC III), 9191 Kearny Villa Court

- 30-kilowatt (AC) rooftop system

- completed 2003

11. Environmental Services Department's Ridgehaven "Green Building" Demonstration Project, 9601 Ridgehaven Court

- 54-kilowatts (AC) rooftop and carport system

- completed May 2003 


\section{Solar America Cities}

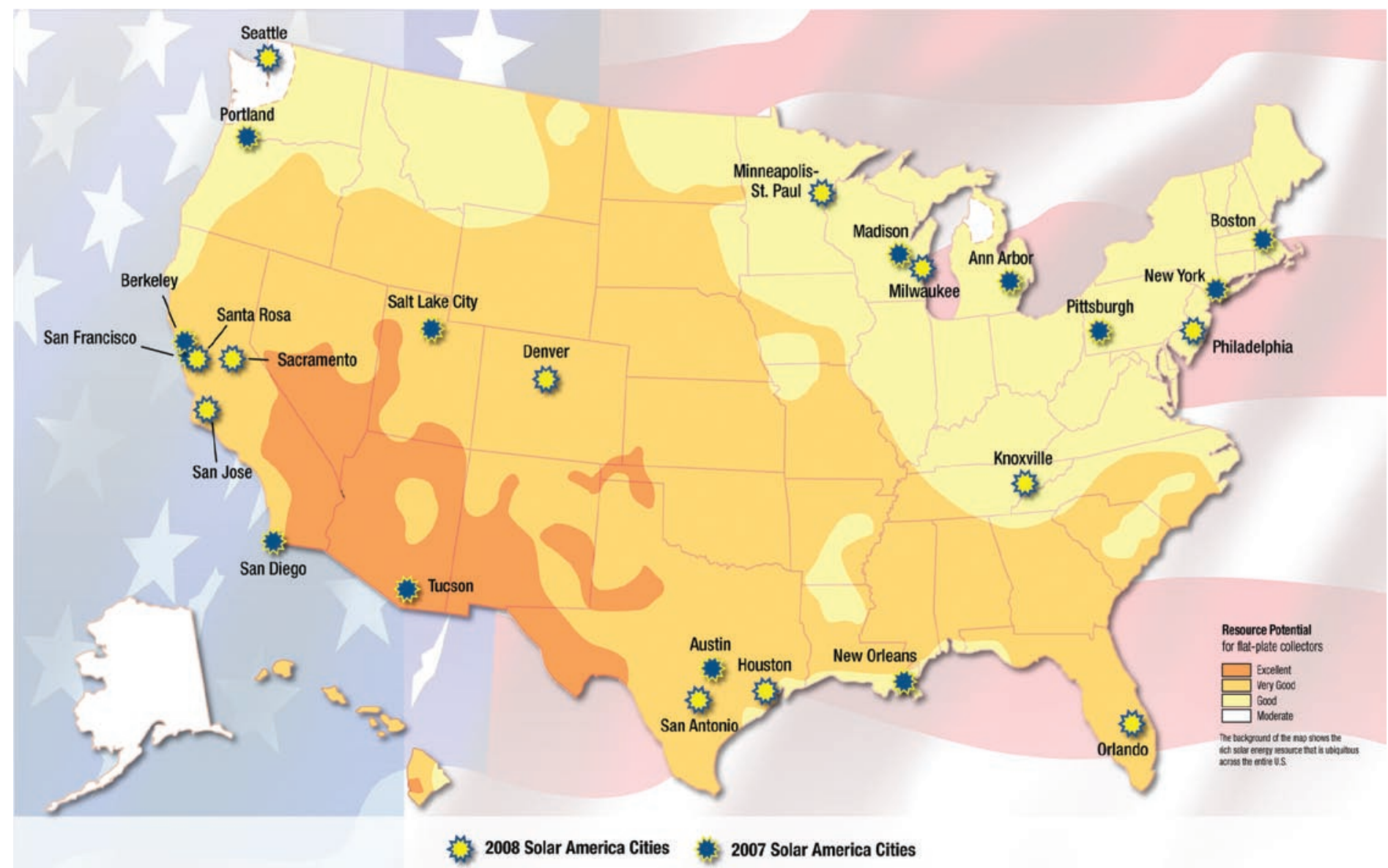

\section{About the Solar America Initiative}

The Solar America Cities awards are part of the Market Transformation efforts of the Solar America Initiative (SAI). President Bush launched SAI in 2006 to accelerate the development of advanced photovoltaic solar technologies with the goal of making them cost-competitive with conventional forms of electricity from the utility grid by 2015 .

The Market Transformation focus of SAI addresses marketplace barriers and offers solar technologies the opportunity for market expansion. The other areas of SAI deal with research and development of solar technology including innovative devices and processes, prototype PV components, and collaborative research and development activities among industry, university, and DOE's national laboratories.

\section{Industry Resources}

\section{Solar Energy Technologies Program}

Funding Opportunities

www.solar.energy.gov/financial opportunities.html

www.solar.energy.gov/solar america/funding opportunities.html

Research and Development

www.solar.energy.gov/solar america/research development.html

Issues and Public Policy

www.solar.energy.gov/solar america/issues public policy.html

Partners Directory

www.solar.energy.gov/solar america/partner.html

\section{Sponsored by the}

U.S. Department of Energy, Office of Energy Efficiency and Renewable Energy

For more information contact:

EERE Information Center

1-877-EERE-INF (1-877-337-3463)

www.eere.energy.gov

Prepared by the

National Renewable Energy Laboratory (NREL)

NREL is a U.S. Department of Energy National Laboratory

Operated by Midwest Research Institute $\bullet$ Battelle

\section{DOE/G0-102008-2603 • May 2008}

A Strong Energy Portfolio for a Strong America. Energy efficiency and clean, renewable energy will mean a stronger economy, a cleaner environment, and greater energy independence for America. Working with a wide array of state, community, industry, and university partners, the U.S. Department of Energy's Office of Energy Efficiency and Renewable Energy invests in a diverse portfolio of energy technologies.

Printed with a renewable-source ink on paper containing at least 50\% wastepaper, including 10\% postconsumer waste. 